\title{
HODNOCENÍ DOPADŮ VYBRANÝCH PROJEKTU゚ DOPRAVNÍ INFRASTRUKTURY NA ŽIVOTNÍ PROSTřEDÍ Z POHLEDU PROSTOROVÝCH NÁROKŮ
}

ENVIRONMENTAL IMPACT EVALUATION OF CHOSEN
INFRASTRUCTURE TRANSPORT PROJECTS WITH EMPHASIS ON
APPROPRIATION OF LAND

\author{
ING. VILÉM PAŘIL \\ \begin{tabular}{l|l} 
Katedra regionální ekonomie a správy & Dep. of Regional Economics and Administration
\end{tabular} \\ Ekonomicko-správni fakulta Faculty of Economics and Administration \\ Masarykova univerzita Masaryk University \\ $\triangle$ Lipová 41a, 60200 Brno, Czech Republic \\ E-mail:vilem@mail.muni.cz
}

\section{Anotace}

Následujici článek je zaměren na hodnoceni dopadů vybraných dopravnich projektů pozemnich komunikací v České republice na životni prostředís důrazem na problematiku záboru pưdy. Jsou zde zkoumány především expresni koridory a cílem je určeni možností jejich vzájemné komparace vzhledem kostatnim rozvojovým souvislostem expresni infrastruktury, prédevším ve vztahu k poptávce. Zkoumány budou stávajíci dopravni tepny i plánované projekty, které vycházejí z dopravní sektorové strategie Ministerstva dopravy $\check{C} R$.
\end{abstract}

\section{Klíčová slova}

dopravní infrastruktura, expresni doprava, dopady na životní prostředí, zábor půdy.

\section{Annotation}

Following article is aimed on environmental impact evaluation of chosen ground transport infrastructure projects in Czech Republic with emphasis on the appropriation of land. The subject of this article is to analyze express transport corridors and the objective is to identify opportunities of project comparison in the relation with the other development circumstances, e.g. in the relation with demand. Analysis includes both current transport projects and even planned projects that come from the long-term transport sector strategy from Ministry of Transport in Czech Republic.

\section{Key words}

transport infrastructure, express transport, environmental impact evaluation, appropriation of land.

JEL classification: $Q 51, R 42$

\section{Úvod}

Problematika výstavby dopravní infrastruktury je bezpochyby velmi důležitou a významnou částí národního hospodářství zajištovanou či financovanou především veřejným sektorem. Je to právě z toho důvodu, že tento statek se velmi blíží naplnění kritérií nerivalitní spotřeby a nevylučitelnosti ze spotřeby, což je předpokladem pro identifikaci veřejného statku (Strecková, Malý, 1998:44-48). Avšak je nutné podotknout, že jednotlivé sektory dopravy i jednotlivé dopravní projekty není možné obecně považovat za čisté veřejné statky, nebot' dle různých okolností jedno ze dvou výše uvedených kritérií nemusí naplňovat a lze je tak řadit spíše do kategorie statků smíšených. Tou částí dopravního sektoru, která je především ovlivňována veřejnou volbou prostřednictvím rozhodování např́ič politicko-byrokratického procesu, je především výstavba, rekonstrukce a údržba či modernizace 
(adaptace na nové technické či poptávkové požadavky) dopravní infrastruktury. Právě tato část dopravního sektoru je téměř výhradně financována veřejným sektorem. Při pohledu do zahraničí je pak zřejmé, že projekty na výstavbu dopravní infrastruktury realizované ve spolupráci se soukromým sektorem nejčastěji selhávají z důvodu chybného odhadu poptávky po dopravě či intenzity dopravy (Řežuchová, 2010:82-83,90). Při zapojení soukromého sektoru do této oblasti tedy dochází k tržním selháním či lépe vyjádřeno $\mathrm{k}$ tržním nedokonalostem, nebot' nejde prakticky o selhání tržního mechanismu, ale spíše jde o projev jeho imanentních vlastností či tendencí (Svoboda, 2007: 561-579). Je tedy možné předpokládat i do budoucna klíčovou roli veřejného sektoru v této oblasti. Předmětem tohoto článku z pohledu vymezení sektoru dopravy je především oblast expresní silniční infrastruktury, tedy sít' rychlostních silnic a dálnic v České republice. Významnost fenoménu silniční dopravy lze snadno reflektovat jen při pohledu na výdaje do oblasti dopravní infrastruktury, které se mezi lety 2000 až 2011 pohybují mezi zhruba 18 až 68 mld. Kč ročně (v průměru 45 mld. Kč), při uvážení pouze dálnic, rychlostních silnic a silnic I., II. a III. tř̌́dy (MD, Ročenky dopravy, 20002011). Dalším důležitým faktem je skutečnost, že poměr investic do silniční dopravní infrastruktury vhledem k výdajům na její opravy a údržbu se ve stejném období v průměru pohyboval v poměru 7:3, což mimo jiné vypovídá o tom, že investice do nové dopravní infrastruktury indukují další nezanedbatelné výdaje na opravu a údržbu těchto komunikací, s jejichž navýšením je nutné počítat i v následujících letech při tvorbě státního rozpočtu či rozpočtů krajských (v př́ípadě II. a III. tříd) a tyto výdaje navíc jsou navíc často mandatorního charakteru ${ }^{1}$. S potřebou výstavby dopravní infrastruktury samozřejmě vznikají nároky nejen na veřejné rozpočty, které jsou explicitně vyjádřeny částkami investovanými do př́slušných projektů, ale vedle těchto finančních dopadů samozřejmě mají jednotlivé projekty i další socio-ekonomické dopady např. na kvalitu podnikatelského prostředí (Viturka, Pařil, Tonev, 2012a:29) nebo dopady environmentálního charakteru. Právě dopady na vybranou environmentální komponentu jsou v tomto článku posuzovány. Sledovanou komponentou a předmětem z hlediska vymezení dopadů na životní prostředí je pak zábor půdy jako jeden z nákladů výstavby silniční dopravní infrastruktury, který zároveň postihuje jeden z téměř výhradně ireversibilních procesů, které jsou výstavbou způsobeny. Hlavním cílem tohoto článku je tedy nastínit možnosti komparace komparativního hodnocení projektů expresní silniční infrastruktury dle reálných či potenciálních dopadů na zábor půdy těmito projekty způsobený. $\mathrm{K}$ tomu je vhodné dodat, že hodnocení jednotlivých staveb podléhá procesu EIA, který je však velmi úzce zaměřený na jednotlivé stavby a neumožňuje tak jejich vzájemnou komparaci. Dokumenty strategického charakteru pak podléhají procesu SEA, který v podstatě vzhledem k rozsahu hodnocené agendy (např. Dopravní politika 2014 až 2020) má spíše obecnější charakter a vedle toho formuluje hlavní problémová místa (u nichž je hodnocení velmi konkrétní, nicméně nikoliv komparativní) ${ }^{2}$.

\section{Metodika hodnocení}

Metodika hodnocení dopadů projektů dopravní infrastruktury vychází z několika zdrojů informací. Základním geografickým nástrojem potřebným ke zmapování nároků expresní silniční dopravní infrastruktury (dále jen D+R) je webový portál http://geoportal.gov.cz, ze kterého byla čerpána data o vedení jednotlivých projektů $\mathrm{D}+\mathrm{R}$ z prostorového hlediska. Východiskem tohoto hodnocení je předpoklad, že pozemek pod sledovanou komunikací původně byl či stále je součástí zemědělského půdního fondu, bylo nebo je tedy možné tento pozemek využívat jiným způsobem užívání či jeho užívání za stanovených podmínek libovolně změnit. Metodika hodnocení pak spočívá v podstatě ve

\footnotetext{
${ }^{1}$ Při podrobnějším pohledu a posouzení výdajů do silniční dopravní infrastruktury ve dvou po sobě jdoucích obdobích, první od roku 2000 do roku 2005 a druhé období od roku 2006 do roku 2011, je zřejmé, že zatímco v prvním období se výdaje na opravy a údržbu v průměru pohybovaly okolo 8,9 mld. Kč ročně, ve druhém období to již bylo 15,55 mld. Kč ročně, což představuje nárůst o 6,65 mld. Kč. Pokud je vzato v potaz, že v prvním období se investovalo do silniční dopravní infrastruktury zhruba 122 mld. Kč (MD, Ročenky dopravy 2000 až 2011), pak lze říci, že každých 18,4 mld. Kč investic do dopravní infrastruktury v prvním období způsobilo navýšení ročních výdajů na její opravy a údržbu v následujícím období o jednu miliardu korun. Vezme-li se v úvahu, že výstavba kilometrového úseku nové dálnice se v ČR pohybuje zhruba od 350 do až téměř 850 mil. Kč, pak znamená výstavba zhruba 20 až 50 kilometrů dálnice budoucí zatížení státního rozpočtu o jednu miliardu korun.

${ }^{2}$ Např. u hodnocení SEA Dopravní politiky 2014 až 2020 byly vybrané jako projekty silniční infrastruktury s potenciálně největšími negativními dopady na veřejné zdraví následující projekty (SEA, Dopravní politika ČR 2014-2020 s výhledem do roku 2050, 2013): R35 (úsek Turnov - Úlibice), R43 (úsek Rozstání - Chornice) a R55 (úsek Bzenec - Mikulčice).
} 
dvou níže srovnávaných př́istupech. Základní přístup hodnocení vychází z vyhlášky 3/2008 Sb. Ministerstva financí o oceňování majetku, oceňovací vyhlášky. Dle této vyhlášky je momentálně evidováno v České republice 2199 bonitně půdně ekologických jednotek v pěti různých třídách ochrany (dle zákona 334/1992 Sb. o ochraně zemědělského půdního fondu, část D), jejichž průměrná cena reflektující koeficienty trríd (dle zákona o ZPF) činí dle poslední novelizace výše zmíněné vyhlášky $15,88 \mathrm{Kč} / \mathrm{m}^{2}$ (dle prrílohy č. $22 \mathrm{k}$ výše zmíněné vyhlášce). Další úprava této ceny pak reflektuje př́ílohu č. 23 této vyhlášky, která reflektuje oceňování těchto pozemků dle jejich polohy na katastrech významných národních, regionálních či mikroregionálních center ${ }^{3}$. Významným faktorem, který tedy ovlivňuje dopady jednotlivých projektů $\mathrm{D}+\mathrm{R}$ z pohledu záboru půdy je poloha a umístění této komunikace ve vztahu ke katastrům obcí. Tato poloha pak může ovlivňovat výsledky při srovnání s pouhým absolutním vyjádřením záboru půdy ve fyzických ukazatelích $\left(\mathrm{m}^{2}\right.$ či ha). $Z$ pohledu záboru půdy jsou zahrnuty nejen samotné komunikace, ale i $\mathrm{k}$ nim přiléhající pásma o šířce 2 metrů na každé straně komunikace, dále víceúrovňové křižovatky či dálniční sjezdy a v neposlední řadě také nároky související infrastruktury, tedy dálničních odpočívek či benzinových stanic.

Rozšířený druhý metodický př́stup využitý $\mathrm{v}$ tomto článku vychází $\mathrm{z}$ př́stupu hodnocení kritéria udržitelnosti (Viturka, Pařil, Tonev, 2012b:254), ale je navázán na výše zmíněný zákon o ZPF (část B). V tomto př́istupu je tedy zohledněno, zdali u jednotlivých projektů $D+R$ dochází ke stykům, respektive územním kolizím s př́rodně významnými lokalitami, přičemž za kolizní pásmo je považováno pásmo do vzdálenosti 500 metrů od okraje komunikace, což je vymezení respektující hlukové znečištění (Viturka, Pařil, Tonev, 2012a:31-32). Území zahrnutá v tomto druhém prrístupu zahrnují především území chráněná dle zákona č. 114/1992 Sb. o ochraně př́rody a krajiny, dále zákona č. 254/2001 o vodách (vodní zákon), a dále zahrnuje i území významná z mezinárodního pohledu - především území vymezená organizací UNESCO jako biosférické rezervace a geoparky, a dále území vymezená Ramsarskou úmluvou jako významné mokřady (v ČR přijata jako Sdělení federálního ministerstva zahraničních věcí 396/1990 Sb.). Z pohledu zákona o ochraně prŕrody a krajiny byly hodnoceny kolizní úseky se zvláště chráněnými územími velkého i malého rozsahu, dále území zahrnutá do Natury 2000, tedy evropsky významné lokality a ptačí oblasti. Z pohledu vodního zákona pak byly hodnoceny kolizní úseky s chráněnými oblastmi přirozené oblasti akumulace vod a ochranná pásma vodních zdrojů (zdrojem pro zmapování této komponenty významných území byl informační portál http://heis.vuv.cz). V jednotlivých kolizních úsecích pak byla cena půdy násobena koeficientem ekologické váhy (zohledňujícím také nezastavěnost daného území v územním plánu). Byly tedy posuzovány následující typy lokalit: národní př́rodní rezervace a jejich ochranná pásma (ekologická váha 20), národní prŕrodní památky a jejich ochranná pásma (ekologická váha 20), př́rodní rezervace a jejich ochranná pásma (ekologická váha 15), př́rodní památky a jejich ochranná pásma (ekologická váha 15), chráněné krajinné oblasti (ekologická váha 15); z hlediska Natury 2000 pak evropsky významné lokality (ekologická váha 15), ptačí oblasti (ekologická váha 20); chráněné oblasti přirozené akumulace vod (ekologická váha 10), ochranná pásma vodních zdrojů (ekologická váha 10); z hlediska mezinárodní ochrany pak ramsarské mokřady (ekologická váha 20), UNESCO biosférické rezervace (ekologická váha 20) a Geopark UNESCO (ekologická váha 10). Zohlednění finanční hodnoty pak lze identifikovat i jako př́nos do analýzy výnosů a nákladů, která je v oblasti dopravy využívána např. i při rozhodování o prostředcích z operačních programů (Halámek, 2011:95).

\section{Výsledky hodnocení}

V následující části jsou zachyceny souhrnné nejvýznamnější výsledky tohoto hodnocení. V tabulce č. 1 jsou zachyceny celkové nároky jednotlivých projektů $\mathrm{D}+\mathrm{R}$ na zábor půdy z pohledu absolutního

\footnotetext{
${ }^{3}$ Pro území hlavního města Prahy je tedy uplatňován koeficient 6,6, pro obce s ním sousedící koeficientu 3,8 a pro obce do vzdálené do 7 kilometrů pak 2,4; dále pro Brno a Ostravu je uplatňován koeficient 4,2, pro sousedící obce 2,6 a pro obce do okolí $5 \mathrm{~km}$ pak 1,8; pro Plzeň a Liberec je uplatňován koeficient 3,4, pro sousedící obce 2,2 a pro obce do vzdálenosti 4 km koeficient 1,6; další kategorí jsou obce mezi 50 a 100 tis. obyvateli, pro které je uplatňován koeficient 3,0, pro sousedící obce 2,0 a pro obce vzdálené do $3 \mathrm{~km}$ pak koeficient 1,5; další zohledněnou kategorií jsou regionální centra odpovídající významnějším bývalým okresním městům s velikostí 25 až 50 tis. obyvatel, pro které je uplatňován koefícient 2,6 a pro obce s nimi sousedící pak koeficient 1,8; posledními zohledněnými kategoriemi jsou obce s 10 až 25 tis. obyvateli (koeficient 2,2), obce s 5 až 10 tis. obyvateli (koeficient 1,8 ) a obce se 2 až 5 tis. obyvateli (koeficient 1,4).
} 
dopadu celkového dopadu na tuto komponentu, který je vyjádřený v hektarech. Ve sloupci „plocharealizace“ jsou zobrazeny nároky částí projektů již realizovaných nebo projektů ve výstavbě. Ve sloupci „plocha-plán“ jsou pak reflektovány nároky plánovaných projektů $\mathrm{D}+\mathrm{R}$ a ve sloupci „plochacelkem“" jsou dopady potenciálně dokončených projektů D+R. Druhá část tabulky č. 1 pak zachycuje celkové náklady na zábor půdy, přičemž je opět respektováno rozdělení na projekty realizované či v realizaci, projekty plánované a na potenciálně dokončené projekty. V této části tabulky jsou uvažovány dvě varianty finančního ohodnocení. První z nich, tzv. minimální varianta“, přesně reflektuje metodiku popsanou výše. Druhá, tzv. „maximální varianta“ pak reflektuje předpoklad nezastavěnosti území z př́lohy B zákona o ZPF (tedy navýšení ceny koeficientem 5).

Tab. 1: Zábor půdy způsobený projekty $D+R$ a jeho potenciální hodnota zpohledu ZPF

\begin{tabular}{|c|c|c|c|c|c|c|c|c|c|}
\hline $\begin{array}{l}\text { Projekty } \\
\text { D+R }\end{array}$ & \begin{tabular}{|l} 
plocha \\
- \\
realizace \\
(ha)
\end{tabular} & $\begin{array}{l}\text { plocha } \\
-\quad \text { plán } \\
\text { (ha) }\end{array}$ & $\begin{array}{l}\text { plocha } \\
\text { - celkem } \\
\text { (ha) }\end{array}$ & \begin{tabular}{|l|} 
Min. \\
náklady \\
$-\quad$ realizace \\
$($ mil. Kč)
\end{tabular} & \begin{tabular}{|l|} 
Max. \\
náklady \\
$-\quad$ realizace \\
$($ mil. Kč)
\end{tabular} & \begin{tabular}{|l} 
Min. \\
náklady \\
$-\quad$ plán \\
(mil. Kč)
\end{tabular} & \begin{tabular}{|l|} 
Max. \\
náklady \\
$-\quad$ plán \\
(mil. Kč)
\end{tabular} & \begin{tabular}{|l|} 
Min. \\
náklady \\
- celkem \\
(mil. Ǩc) \\
\end{tabular} & $\begin{array}{l}\text { Max. } \\
\text { náklady } \\
\text { - celkem } \\
\text { (mil. Kč) }\end{array}$ \\
\hline D1 & 1806 & 70 & 1876 & 596 & 2981 & 21 & 104 & 617 & 3085 \\
\hline $\mathrm{R} 1$ & 291 & 155 & 446 & 260 & 1298 & 141 & 706 & 401 & 2004 \\
\hline D2 & 256 & 0 & 256 & 75 & 375 & 0 & 0 & 75 & 375 \\
\hline D3-vV & 78 & 490 & 568 & 22 & 111 & 104 & 518 & 126 & 629 \\
\hline D3-vZ & 78 & 513 & 591 & 22 & 111 & 110 & 551 & 132 & 662 \\
\hline $\mathrm{R} 4$ & 215 & 130 & 345 & 83 & 415 & 25 & 124 & 108 & 539 \\
\hline D5 & 776 & 0 & 776 & 200 & 1001 & 0 & 0 & 200 & 1001 \\
\hline R6 & 383 & 264 & 647 & 130 & 648 & 58 & 289 & 187 & 937 \\
\hline R7 & 222 & 132 & 354 & 66 & 328 & 30 & 150 & 95 & 477 \\
\hline D8 & 426 & 0 & 426 & 104 & 520 & 0 & 0 & 104 & 520 \\
\hline $\mathrm{R} 10$ & 329 & 0 & 329 & 106 & 528 & 0 & 0 & 106 & 528 \\
\hline D11 & 393 & 199 & 592 & 113 & 566 & 54 & 272 & 168 & 839 \\
\hline R35-vJ & 475 & 535 & 1011 & 141 & 704 & 109 & 546 & 250 & 1250 \\
\hline R35-vS & 475 & 520 & 996 & 141 & 704 & 104 & 522 & 245 & 1225 \\
\hline R35-vSS & 446 & 548 & 994 & 135 & 675 & 112 & 559 & 247 & 1234 \\
\hline $\mathrm{R} 43$ & 18 & 231 & 250 & 10 & 48 & 58 & 292 & 68 & 340 \\
\hline $\mathrm{R} 46$ & 168 & 0 & 168 & 49 & 247 & 0 & 0 & 49 & 247 \\
\hline $\mathrm{R} 48$ & 265 & 42 & 307 & 71 & 353 & 18 & 90 & 89 & 443 \\
\hline R49 & 0 & 183 & 183 & 0 & 0 & 42 & 209 & 42 & 209 \\
\hline R52-vV & 0 & 39 & 39 & 0 & 0 & 16 & 80 & 16 & 80 \\
\hline R52-vZ & 65 & 103 & 168 & 12 & 62 & 25 & 126 & 37 & 187 \\
\hline R55 & 85 & 270 & 355 & 23 & 115 & 72 & 358 & 95 & 473 \\
\hline R56 & 107 & 0 & 107 & 58 & 288 & 0 & 0 & 58 & 288 \\
\hline R63 & 21 & 0 & 21 & 6 & 31 & 0 & 0 & 6 & 31 \\
\hline
\end{tabular}

Zdroj: www.geoportal.gov.cz, př́lohy č. 22 a 23 k vyhlášce č. 3/2008 Sb., část B a D zákona 334/1992 o ochraně ZPF, vlastní zpracování

V tabulce č. 2 je zobrazeno pořadí jednotlivých projektů z pohledu záboru půdy a z pohledu jejího finančního ocenění (kde platí, že čím nižší je pořadové číslo, tím nižší jsou potenciální náklady). Řada výsledků je samozřejmě očekávatelná, nebot' jsou hodnoceny celkové nároky, a tedy cena je jednoznačně ovlivňována celkovou délkou dané komunikace (kromě jiného), nicméně naproti tomu jsou u několika projektů zahrnuty i jednotlivá nejdůležitější variantní řešení, která zobrazují jejich potenciální náklady na zábor půdy ${ }^{4}$.

\footnotetext{
${ }^{4} \mathrm{Z}$ tohoto pohledu jsou nejzajímavějším projekty R52 (varianta východní - vV a varianta západní - vZ), D3 (varianta východní - vV a varianta západní - vZ) a R35 (varianta superseverní - vSS, varianta severní - vS a varianta jižní - vJ).
} 
Tab. 2: Pořadí projektů dle nároků na zábor půdy - celkové nároky dokončených projektů

\begin{tabular}{|l|r|r|l|r|r|}
\hline $\begin{array}{l}\text { Celkové } \\
\text { nároky } \\
\text { /D+R }\end{array}$ & $\begin{array}{l}\text { ZPF - } \\
\text { plocha }\end{array}$ & $\begin{array}{l}\text { ZPF } \\
\text { náklady }\end{array}$ & $\begin{array}{l}\text { Celkové } \\
\text { nároky } \\
\text { /D+R }\end{array}$ & $\begin{array}{l}\text { ZPF - } \\
\text { plocha }\end{array}$ & $\begin{array}{l}\text { ZPF - } \\
\text { náklady }\end{array}$ \\
\hline R63 & 1 & 1 & R10 & 10 & 13 \\
\hline R52-vV & 2 & 2 & R4 & 11 & 14 \\
\hline R52-vZ & 4 & 3 & D3-vV & 16 & 15 \\
\hline R49 & 6 & 4 & D3-vZ & 17 & 16 \\
\hline R46 & 5 & 5 & D11 & 18 & 17 \\
\hline R56 & 3 & 6 & R6 & 19 & 18 \\
\hline R43 & 7 & 7 & D5 & 20 & 19 \\
\hline D2 & 8 & 8 & R35-vS & 22 & 20 \\
\hline R48 & 9 & 9 & R35-vSS & 21 & 21 \\
\hline R55 & 13 & 10 & R35-vJ & 23 & 22 \\
\hline R7 & 12 & 11 & R1 & 15 & 23 \\
\hline D8 & 14 & 12 & D1 & 24 & 24 \\
\hline
\end{tabular}

Zdroj: www.geoportal.gov.cz, prílohy č. 22 a 23 k vyhlášce č. 3/2008 Sb., část B a D zákona 334/1992 o ochraně ZPF, vlastní zpracování

Zřejmě zajímavější pohled na pořadí je pak zobrazen v tabulce č. 3 , kde jsou uvažovány pouze plánované projekty $\mathrm{D}+\mathrm{R}$. Zde bezpochyby zajímavým výsledkem je umístění východní varianty $\mathrm{R} 52$ o 3 a 4 místa před západní variantu, kde navíc není zohledněna skutečnost, že při realizaci západní varianty bude nutné vybudovat dvoupruhový obchvat Břeclavi ze směru plánované R55. Při zvážení této skutečnosti bude při realizaci západní varianty realizován úsek třikrát delší než v prŕpadě východní varianty, a to i z pohledu záboru půdy, což koreluje s dalšími již konstatovanými pochybeními ze strany např. Nejvyššího kontrolního úřadu, Ekologického právního servisu či výzkumné společnosti Motran Research, zabývající se dopravním plánováním (EPS, 2006; NKÚ, 2008; Motran 2013). Dalším zajímavým výsledkem je projekt D3, kde jeho západní varianta z pohledu záboru půdy nepotvrzuje ,šetrnost“ preferované varianty ŘSD oproti variantě východní. Problematika variant R35 je pak diskutována níže. U projektu R1 je patrný významný posun v umístění při zohlednění finanční hodnoty oproti ukazateli rozlohy (o deset míst). Tato skutečnost je evidentně způsobena metodikou hodnocení a polohou této stavby, která se nachází výlučně na území hlavního města Prahy či v obcích k ní bezprostředně přiléhajících.

V tabulkách 4 a 5 jsou pak uvedeny minimální a maximální varianty korespondující s výše popsanou metodikou, které vyčíslují potenciální či již realizované náklady na zábor půdy u jednotlivých projektů $\mathrm{D}+\mathrm{R}$ při zohlednění kolizních úseků $\mathrm{s}$ výše popsanými př́rodně cennými lokalitami z pohledu české legislativy, evropských směrnic i vybraných mezinárodních úmluv. V tabulce 4 jsou zachyceny celkové dopady potenciálně dokončených projektů $\mathrm{D}+\mathrm{R}$ a jejich pořadí od nejmenšího zásahu po největší.

V tabulce 5 jsou pak uvažovány pouze projekty plánované a jejich vzájemné pořadí. Pozornost je vhodné věnovat opět variantním řešením. Postup rozšířenou metodikou potvrzuje předchozí výsledky jak u R52, tak u D3 (kde se v obou př́ípadech jeví východní varianta jako šetrnějšíi). Naopak u R35 se pořadí mění a varianta severní ohodnocená $\mathrm{v}$ předchozí části nejlepším umístěním se dostává zohledněním př́rodních lokalit až na poslední místo ze všech tř́i uvažovaných variant, přičemž za nejšetrnější z pohledu záboru půdy se v tomto případě jeví varianta jižní. Dalšími projekty, které se umíst'ují z hlediska celkových dopadů ve spodní části tabulky, jsou pak R43, R1, R6 a R55. 
Tab. 4: Pořadí projektů dle celkových nároki̊ na zábor půdy při zohlednění chráněných území

\begin{tabular}{|c|c|c|c|c|c|c|c|c|}
\hline \multirow{2}{*}{$\begin{array}{l}\text { Projekty } \\
\text { D+R }\end{array}$} & \multicolumn{2}{|c|}{ ZPF } & \multirow{2}{*}{$\begin{array}{l}\text { ZCHÚ } \\
\text { náklady } \\
\text { celkem } \\
\text { (mil. Kč) }\end{array}$} & \multirow{2}{*}{\begin{tabular}{|l|} 
CHOPAV \\
náklady \\
celkem \\
(mil. Kč) \\
\end{tabular}} & \multirow{2}{*}{\begin{tabular}{|l|} 
OPVZ \\
náklady \\
celkem \\
(mil. Kč)
\end{tabular}} & \multicolumn{3}{|c|}{ Celkem } \\
\hline & \begin{tabular}{|l|} 
Min. \\
náklady \\
celkem \\
(mil. Kč)
\end{tabular} & $\begin{array}{l}\text { Max. } \\
\text { náklady } \\
\text { celkem } \\
\text { (mil. Kč) }\end{array}$ & & & & $\begin{array}{l}\text { CELKEM } \\
\text { MIN. }\end{array}$ & $\begin{array}{l}\text { CELKEM } \\
\text { MAX. }\end{array}$ & Pořadí \\
\hline R63 & 6 & 31 & 17 & 0 & 0 & 23 & 48 & 1 \\
\hline R46 & 49 & 247 & 22 & 5 & 0 & 76 & 273 & 2 \\
\hline R56 & 58 & 288 & 11 & 0 & 0 & 69 & 299 & 3 \\
\hline R52-vV & 16 & 80 & 222 & 63 & 10 & 311 & 375 & 4 \\
\hline R49 & 42 & 209 & 45 & 113 & 88 & 288 & 455 & 5 \\
\hline R48 & 89 & 443 & 61 & 0 & 4 & 153 & 507 & 6 \\
\hline R52-vZ & 37 & 187 & 429 & 0 & 24 & 490 & 640 & 7 \\
\hline R7 & 95 & 477 & 92 & 83 & 1 & 272 & 654 & 8 \\
\hline R43 & 68 & 340 & 178 & 0 & 178 & 423 & 695 & 9 \\
\hline R4 & 108 & 539 & 132 & 0 & 66 & 306 & 737 & 10 \\
\hline D2 & 75 & 375 & 251 & 121 & 0 & 447 & 747 & 11 \\
\hline R55 & 95 & 473 & 422 & 103 & 98 & 718 & 1097 & 12 \\
\hline D8 & 104 & 520 & 384 & 148 & 69 & 705 & 1121 & 13 \\
\hline R10 & 106 & 528 & 200 & 255 & 145 & 706 & 1129 & 14 \\
\hline D3-vV & 126 & 629 & 268 & 214 & 164 & 771 & 1274 & 15 \\
\hline D3-vZ & 132 & 662 & 263 & 214 & 159 & 768 & 1298 & 16 \\
\hline D11 & 168 & 839 & 200 & 150 & 175 & 693 & 1364 & 17 \\
\hline D5 & 200 & 1001 & 346 & 0 & 103 & 650 & 1451 & 18 \\
\hline R6 & 187 & 937 & 618 & 228 & 80 & 1112 & 1862 & 19 \\
\hline R1 & 401 & 2004 & 283 & 0 & 22 & 705 & 2308 & 20 \\
\hline R35-vSS & 247 & 1234 & 872 & 516 & 122 & 1756 & 2744 & 21 \\
\hline R35-vJ & 250 & 1250 & 790 & 604 & 103 & 1747 & 2747 & 22 \\
\hline R35-vS & 245 & 1225 & 879 & 661 & 128 & 1913 & 2894 & 23 \\
\hline D1 & 617 & 3085 & 555 & 104 & 368 & 1645 & 4113 & 24 \\
\hline
\end{tabular}

Zdroj: www.geoportal.gov.cz, př́lohy č. 22 a 23 k vyhlášce č. 3/2008 Sb., část B a D zákona 334/1992 o ochraně $Z P F$, vlastni zpracování

Tab. 5: Pořadí plánovaných projektů dle nároků na zábor půdy při zohlednění chráněných území

\begin{tabular}{|c|c|c|c|c|c|c|c|c|}
\hline \multirow{2}{*}{$\begin{array}{l}\text { Projekty } \\
\text { D+R }\end{array}$} & \multicolumn{2}{|c|}{ ZPF } & \multirow{2}{*}{\begin{tabular}{|l|} 
ZCHÚ \\
náklady \\
plán (mil. \\
Kč)
\end{tabular}} & \multirow{2}{*}{$\begin{array}{l}\text { CHOPAV } \\
\text { náklady } \\
\text { plán (mil. } \\
\text { Kč) }\end{array}$} & \multirow{2}{*}{$\begin{array}{l}\text { OPVZ } \\
\text { náklady } \\
\text { plán (mil. } \\
\text { Kč) }\end{array}$} & \multicolumn{3}{|c|}{ Celkem } \\
\hline & $\begin{array}{l}\text { Min. } \\
\text { náklady } \\
\text { plán (mil. } \\
\text { Kč) }\end{array}$ & $\begin{array}{l}\text { Max. } \\
\text { náklady } \\
\text { plán (mil. } \\
\text { Kč) }\end{array}$ & & & & $\begin{array}{l}\text { CELKEM } \\
\text { MIN. - } \\
\text { plán }\end{array}$ & \begin{tabular}{|l|} 
CELKEM \\
MAX. - \\
plán
\end{tabular} & Pořadí \\
\hline R48 & 18 & 90 & 52 & 0 & 0 & 70 & 142 & 1 \\
\hline R4 & 25 & 124 & 19 & 0 & 8 & 51 & 150 & 2 \\
\hline D1 & 21 & 104 & 0 & 52 & 0 & 73 & 156 & 3 \\
\hline R7 & 30 & 150 & 21 & 0 & 0 & 51 & 171 & 4 \\
\hline R52-vV & 16 & 80 & 222 & 63 & 10 & 311 & 375 & 5 \\
\hline R49 & 42 & 209 & 45 & 113 & 88 & 288 & 455 & 6 \\
\hline D11 & 54 & 272 & 0 & 150 & 121 & 325 & 543 & 7 \\
\hline R52-vZ & 25 & 126 & 429 & 0 & 0 & 454 & 555 & 8 \\
\hline R43 & 58 & 292 & 173 & 0 & 178 & 409 & 642 & 9 \\
\hline R1 & 141 & 706 & 0 & 0 & 0 & 141 & 706 & 10 \\
\hline R6 & 58 & 289 & 499 & 56 & 8 & 621 & 852 & 11 \\
\hline R55 & 72 & 358 & 422 & 103 & 64 & 661 & 948 & 12 \\
\hline D3-vV & 104 & 518 & 268 & 214 & 131 & 716 & 1130 & 13 \\
\hline D3-vZ & 110 & 551 & 263 & 214 & 126 & 713 & 1154 & 14 \\
\hline R35-vJ & 109 & 546 & 328 & 399 & 59 & 896 & 1333 & 15 \\
\hline R35-vSS & 112 & 559 & 414 & 364 & 84 & 975 & 1422 & 16 \\
\hline R35-vS & 104 & 522 & 418 & 456 & 84 & 1062 & 1479 & 17 \\
\hline
\end{tabular}

Zdroj: www.geoportal.gov.cz, př́lohy č. 22 a 23 k vyhlášce č. 3/2008 Sb., část B a D zákona 334/1992 o ochraně $Z P F$, vlastní zpracováni 


\section{Závěr}

Závěrem tohoto př́spěvku lze konstatovat několik zajímavých zjištění. Při hodnocení dopadů projektů silniční dopravní infrastruktury na vybranou environmentální charakteristiku, tj. v podstatě ireversibilní zábor půdy, lze uplatňovat přístup vyjádření tohoto dopadu prostřednictvím základních fyzikálních veličin (v tomto případě např. hektarů) nebo prostřednictvím finančního ocenění. Pokud je brána vúvahu pouze půda jako zdroj (u kterého se dále nerozlišuje jeho míra ochrany či významnosti), pak oba tyto dva způsoby hodnocení spějí k velmi podobným výsledkům, potažmo závěrům (s výjimkou např. projektu R1 ovlivněného prostorovým umístěním okolo Prahy). Zajímavými zjištěními je pak potvrzení problematičnosti některých variantních řešení (např. R52 či D3). Nicméně pokud je brána $\mathrm{v}$ potaz finanční hodnota tohoto faktoru reflektující jeho př́rodní významnost či jedinečnost (dle míry ochrany), pak se tyto způsoby hodnocení určitým způsobem rozcházejí a spějí k odlišným výsledkům (viz např. variantní řešení R35). Na druhou stranu lze konstatovat, že obdobných výsledků by zřejmě bylo dosaženo $\mathrm{v}$ případě, že by se nevyužilo finančního ocenění, ale jednotlivé absolutní dopady ve fyzikálních veličinách by byly váženy stejnými koeficienty (vycházejícími ze současné legislativy), jakými byla ovlivněna dosažená finanční hodnota tohoto specifického nákladu výstavby expresních silnic. Vedle toho je také vhodné zmínit, že právě faktor záboru půdy a jeho zahrnutí do rozhodování o realizaci dopravních projektů nejen expresní silniční infrastruktury velmi silně koreluje s délkou těchto dopravních projektů, a tedy i s celkovými náklady na jejich výstavbu, respektive s jejich kapitálovou přiměřeností, která by měla být sledována i v oblasti veřejného sektoru, např. při rozdělování prostředků z operačních programů (Halámek, Opluštilová, 2010:215-223).

\section{Literatura}

[1] Ekologický právní servis. Př́padová studie - EIA - Dopravní infrastruktura, Rychlostní silnice R52 Pohořelice - Mikulov (Drasenhofen). 2006.

[2] HALÁMEK, P., OPLUŠTILOVÁ, I. Kapitálová přiměřenost municipálních projektů financovaných z ROP JV. In XIII. mezinárodni kolokvium o regionálních vědách. Sborník př́spěvků. Brno: Masarykova univerzita, 2010. s. 215-223. ISBN 978-80-210-5210-9.

[3] HALÁMEK, P. Aplikace CBA při implementaci OP v ČR. In XIV. mezinárodní kolokvium o regionálních védách. Sborník př́spěvkỉ. Brno: Masarykova univerzita, 2011. s. 90-99. ISBN 978-80-210-5513-1.

[4] Ministerstvo dopravy ČR. Ročenky dopravy 2000 až 2011. Praha, 2011. [cit. 1. 4. 2013] Dostupné z: $<$ https://www.sydos.cz/cs/rocenky.htm>.

[5] Ministerstvo financí.Vyhláška 3/2008 Sb. O oceňováni majetku, oceňovací vyhláška, dle novelizace 450/2012 Sb. Praha, 2013 [cit. 5. 4. 2013] Dostupné z: <http://portal.gov.cz>.

[6] Ministerstvo životního prostředí. SEA - Dopravní politika ČR 2014-2020 s výhledem do roku 2050. Praha, 2013. [cit. 1. 4. 2013] Dostupné na webových stránkách informačního systému SEA, Agentura CENIA: <http://portal.cenia.cz/eiasea/detail/SEA_MZP141K >.

[7] Motran Research, s.r.o. (2013). Dopravní studie variant rychlostní silnice R55 a silničního spojeni Brna a Vídně. [cit. 15. 4. 2013] Dostupné z: <http://www.motran.info >.

[8] Nejvyšší kontrolní úřad (2008). Věstník NKÚ 2008, př́pad 08/26, s. 191-204.

[9] ŘEŽUCHOVÁ, M. Fenomén Public - private Partnerships a poskytováni veřejných služeb. Brno: Masarykova univerzita, 2010, $176 \mathrm{~s}$.

[10] STRECKOVÁ, Y., MALÝ, I. a kol. Veřejná ekonomie pro školu i praxi. Brno: Computer Press, 1998. ISBN 80-7226-112-6, s. 214.

[11]SVOBODA, F. Za obzor neoklasické ekonomie: Cesta k principům nové institucionální ekonomie. Politická ekonomie, 2007. vol. 55, no. 4, s. 561-579. ISSN 0032-3233.

[12] VITURKA, M., PAŘIL, V. a TONEV, P. (2012a). Nová metoda komparativního hodnocení účelnosti projektů výstavby dopravní infrastruktury. Urbanismus a územni rozvoj, Brno: ÚÚR MMR ČR, 2012, XV, č. 2, s. 28-34. ISSN 1212-0855.

[13] VITURKA, M., PAŘIL, V. a TONEV, P. (2012b). Př́spěvek k hodnocení společenských dopadů projektů výstavby expresních silnic. In $X V$. mezinárodni kolokvium o regionálních védách. Sbornik príspěvkỉ. Brno: Masarykova univerzita, 2012. s. 250-256. ISBN 978-80-210-5875-0. 